\title{
Analisis Semiotika Petikan Puisi pada Drama Hamlet (Prince of Denmark) Karya Shakespeare
}

\author{
Heni \\ STIKOM Uyelindo Kupang \\ Heniheni8monika@gmail.com
}

\begin{abstract}
Abstrak
Semiotika dalam tindak penelitian sastra menjadi salah satu pendekatan, yang terhitung kerap digunakan dalam ragam penelitian sastra. Dalam terminologi sastra,teori semiotik sangat penting karena sistem bahasa dalam sastra merupakan sistem bahasa kedua. sisana terdapat penanda dan petanda. Sistem bahasa adalah lambang/tanda, sehingga dalam sastra, bahasa yang dikonsumsi bukan bahasa biasa melainkanbahasa puitika. untuk lebih jelasnya kita akan melihat teori semiotik ini meliputi; historisitas, pendekatan, teori, prosedur (metode), asumsi tentang tentang karya sastra dan kelebihan juga kekurangannya. Semiotika dalam tindak penelitian sastra menjadi salah satu pendekatan, yang terhitung kerap digunakan dalam ragam penelitian sastra. Petikan puisi Hamlet memiliki beberapa tanda yang dapat dianalisis dalam semiotika. Penggalian nilai dan makna melalui tanda-tanda yang terdapat pada karya sastra tentunya akan terkait erat dengan semiotika yang memilki fokus pada sistem tanda. Terkait dengan tindakan analisis semiotic terhadap karyas astra, pada fokus pembicaraan ini, maka penelitian sastra (semiotika) akan melibatkan bahasa yang dianggap sebagai media komunikasi dalam bentuk bahasa yang memuat banyak system tanda.
\end{abstract}

Kata Kunci: Hamlet, semiotika, sastra, tanda

\begin{abstract}
In literary terminology, the semiotic theory is very important because the language system in literature is a second language system, where there are markers and markers, the language system is a symbol/sign so that in literature, the language that is consumed is not ordinary, especially poetic language. for more details, we will see this semiotic theory includes; historicity, approaches, theories, procedures (methods), assumptions about literary works, and excellence are also lacking. Hamplet poetry has many signs that canbe analized with emiotics. Semiotics in the act of literary research is one approach, which is often used in a variety of literary research. The exploration of values and meanings through signs contained in literary works will certainly be closely related to semiotics which has a focus on the sign system. Regarding the action of semiotic analysis on literary works, in the focus of this book's discussion, literary research (semiotics) will involve language which is considered as a communication medium in the form of language which contains many sign systems.
\end{abstract}

Keywords: Hamlet, semiotics, literature, signs 


\section{Pendahuluan}

Semiotika merupakan salah satu kajian sastra yang membahas makna tanda. Pada pemahaman kajian sastra semiotika, semua karya sastra memiliki makna tanda sebagai pembangun karya, dan tanda dipahami melalui kajian semiotika. Dengan demikian pembaca dan penikmat sastra mampu menemukan makn ayang diungkapkan pengarang. Serangkaian kajian sastra berfungsi dalam mengembangkan ilmu sastra dan karya sastra melalui ragam kajian, salah satunya semiotikan yang dapat pula berfungsi sebagai acuan dalam proses penelitian karya ilmiah berupa buku panduan. Oleh karena itu, disajikan buku panduan yang khusus menuntun pembaca dalam memahami karya sastra melalui pemahaman makna tanda.

Tindak penelitian secara umum memerlukan metode, pendekatan dan teknik. metode akan berfungsi sebagai batasan cara dalam melakukan tindak penelitian yang akan diterapkan dan telah diputuskan sebagai cara yang sesuai. Pisau yang akan dipergunakan dalam menelusuri objek pada penelitian dapat disebut sebagai pendekatan Atau dapat juga dipahami bahwasanya pendekatan merupakanp erspektif yang membangun wilayah dan lingkup dalam tindak analisis. Teknik merupakan bentuk operasional yang diterapkan dalam proses tindak penelitian sastra tersebut. Dalam penelitian sastra, beragam pendekatan dapat diplih untuk mendukung proses penelitian. Seperti yang telah diungkapkan, bahwa fungsi pendekatan dalam penelitian sastra adalah sebagai mata pisau yang dipergunakan untuk menggali secara analisis.

Penggalian nilai dan makna melalui tanda-tanda yang terdapat pada karya sastra tentunya akan terkait erat dengan semiotika yang memilki fokus pada sistem tanda. Terkait dengan tindakan analisis semiotic terhadap karya sastra, pada focus pembicaraan buku ini, penelitian sastra (semiotika) akan melibatkan bahasa yang dianggap sebagai media komunikasi dalam bentuk bahasa yang memuat banyak system tanda.

Kajian semiotic membawa pada asumsi bahwa kajian tersebut merupakan kajian yang diterapkan pada karya sastra yang juga merupakan sistem tanda, berfungsi sebagai sarana komunikasi estetis. Sarana yang akan menghubungkan karya sastra dengan makna dan nilai-nilai yang terkandung untuk dipahami melalui proses intepretasi terhadap sintagma dan paradigma sebuah karya sastra. Tindak penelitian sastra dengan menggunakan pendekatan semiotik dapat dikatakan merupakan perkembangan dan penerusan dari aliran strukturalisme sebagai aliran yang melahirkan ilmu pada masa yang terdahulu, seperti yang telah disampaikan sebelumnya. Oleh Karena karya sastra merupakan struktur tanda yang bermakna, maka memahaminyapun tidak dapat dilepaskan dari struktur pembangun karya sastra. Secara umum, karya sastra terbangun oleh unsur-unsur, baik yang tampak atau secara eksplisit, maupun secara implisit. Untuk dapat memahami segala unsur karya sastra secara optimal berarti harus memahami, sistem tanda, tanda, konvensi makna, dan konvensi tanda.

Halaman | 63 


\section{Landasan Teori}

Beberapa ahli mengatakan bahwasa memahami karya sastra dengan pendekatan Semiotik juga dapat dilakukan dengan menempuh empat langkah, seperti yang diungkapkan oleh Wardoyo(2004) sebagai ancangan Semiotik, antara lain; Langkah1) yaitu mencari signifier utamayang dapat merepresentasikan seluruh inti karya sastra. Dapat pula mencari apa yang bisa dianggap sebagai penanda utama yang dapat mempresentasikan ini seluruh karya sastra. Langkah2) yaitu membuat analisis sintagmatig atau paradigmat ikuntuk mencari detail pendukung signifier utama. Dalam melakukan analisa paradigmatic dapat ditetap kan sebuah oposisi biner yang seirama dengan signifier utama. Langkah 3) yaitu untuk mendukung lebih lanjut signifier utama dapat ditetapkan dalam langkah pertama yang dilengkapi dengan analisa sintagmatik. Selain itu fungsi analisa sintagmatik adalah mencari kaitan antara sekian banyak paradigmatic yang muncul dalam karya sastra. Langkah 4) yaitu melakukan analisis sintagmatik.

Kajian semiotic yang mengungkap karya sastra melalui system tangda sebagai sarana komunikasi yang bersifat estetis, pembagian sarana komunikasi (Segers,2000) dapatdi pergunakan secara terpisah dengan dilengkapi perincian agar menjadi jelas. Substansi dalam tanda (Suwardi,2004) yang memuat substan ekspresi, isi, dan bentuk isi, penanda sebagai sesuatu yang formal, dan petanda sebagai konsep representasi dari penanda selalu berhubungan. Secara bebas, memahami karya sastra dengan pendekatan semiotic dapat mengacu pada beberapa konsep teori semiotik, seperti Peirce ataupun Riffatere dengan mengembalikan orientasi pencapaian dan fokus penelitian.

Dilihat dari aspek historisnya kemunculan teori dan pendekatan semiotik ini, muncul dari ketidakpuasan terhadap pendekatan struktural yang hanya terbatas pada aspek kajiaan interistik saja. Padahal sastra dipandang mempunyai sistem sendiri tidak terlepas dari masalah penciptaan, ekspresi penulis, dan masalah penerimaan karya sastra oleh pembaca. Tokoh yang paling berpengaruh dalam perkembangan semiotik ialah Ferdinand Sauser (1857-1913) seorang ahli linguistik dari Perancis dan seorang ahli filsafat bermadhab Anglo-Amerika yang bernama Charles Sander Pierce (1839-1913). Sausere menyebut ilmu tersebut dengan istilah Semiologi, sedangkan Pierce menyebutnya dengan istiah semiotika. Belum lagi ada refatie yang kajian semiotiknya sangat relevan untuk menganalisis bahasa dalam puisi.

Pendekatan semiotik merupakan sebuah pendekatan yang memiliki sistem sendiri, berupa sistem tanda atau kode. Tanda dan kode itu dalam sastra dapat disebut estetis, yang secara potensial diberikan dalam suatu komunikasi, baik yang terdapat di dalam struktur teks maupun luar strukturnya teks karya tersebut. Kode yang bersifat tanda itu mempunyai banyak interpretasi makna dan memiliki pluralitas makna yang luas tergantung tingkat repertoa sipembaca ketika memberi penilaian terhadap teks karya yang dikaji. Setiap pembaca sastra mesti menyadari bahwa ia sedang berhadapan denga teks yang berbeda dengan teks yang lain. 
Secara spesifik,pendekatan Semiotik khusus meneliti sastra yang dipandang memiliki sistem sendiri, sedangkan sistem itu berurusan dengan masalah tekhnik, mekanisme penciptaan, masalah ekspresi dan komunikasi, dan bila kajiannya sudah dikaitkan dengan masalah ekspresi dan manusia, bahasa, situasi, isyarat, stalistika, style dan sebagainya, Hal itu sudah mencapai kajiaan semiotik menyangkut aspek eksteristik dan interistik karya sastra.Dalam ketidakberdayaan Hamlet bersamaan dengan dirinya yang tengah dilingkupi oleh perasaan bimbang, termanifestasi dalam sebuah monolog terkenal "to be, or not to be". Hamlet yang bimbang dalam keinginan untuk menjatuhkan putusan, antara betindak atau tidak bertindak. Karena masing-masing dari kedua putusan tersebut memiliki konsekuensi tersendiri yang akan Hamlet terima. Jika ia memilih untuk bertindak, itu sama saja berarti bahwa ia memilih untuk hidup (to be), tetapihidupnya akan penuh dengan penderitaan atas kepengecutannya yang hanya bisa pasrah dan menyerah kalah terhadap keadaan yang ada. Sebaliknya, jika ia memilih untuk tidak bertindak, itu sama artinya dengan mati (not to be), mati dalam hal ini terkait dengan keberanian dan semangat untuk melawan keadaan yang ada.

Petikan puisi Hamlet prince of Denmark memiliki beberapa tanda yang dapat dikaji atau dianalisis dengan menggunakan ilmu semiotik. Kalimat-kalimat yang terdapat dalam puisi Hamlet memiliki parafrase yang akan dijabarkan dalam beberapa tanda atau makna. Hamlet yang tengah dirundung bingung dalam menjatuhkan putusan untuk bertindak atau tidak bertindak. Pada masa-masa bimbangnya itu, jiwanya bergejolak, ia depresi, sampai suatu ketika ia mengalami kelumpuhan. Kelumpuhannya itu berlangsung hingga Hamlet benar-benar mampu membuat satu keputusan yang pasti dan jujur.Dalam pengamatan secara psikologis, ekspresi bimbang dan ragu-raguHamlet termanifestasikan dalam suatu bentuk monolog "to be, or not to be". Monolog itumengandung kesan ganjil, seolah ada pesan tersirat di baliknya. Dalam drama tragis Hamlet tersebut, pada mulanya dikisahkan bahwa, ayah Hamlet yang merupakan seorang raja Denmark, ia dibunuh oleh adik kandungnya sendiri bernama Claudius (paman Hamlet). Setelah Claudius berhasil membunuh ayah Hamlet, ia lalu menikahi ibunya, Ratu Gertrude.Secara otomatis, Claudius pun naik tahta menjadi raja Denmark menggantikan posisi ayah Hamlet.Pada suatu ketika, Hamlet dihantui arwah ayahnya yang kemudian menyuruh Hamlet untuk membalaskan dendamnya terhadap Claudius karena telah membunuhnya. Hamlet pun akhirnya bertekad membunuh pamannya, Claudius. Walaupun diakhir cerita, Hamlet berhasil membunuh pamannya dan ia sendiri pun akhirnya tewas. Sikap ragu dan bimbang Hamlet dalam monolog tersebut tetap masih menjadi misteri. Kiranya hal apakah yang menyebabkan Hamlet ragu dan bimbang ?Mengapa ia tidak sanggup memutuskan untuk bertindak cepat dan langsung membuat keputusan ?Bahkan dikisahkan pula bahwa Hamlet sempat berpura-pura menjadi gila dan bahkan ia juga sempat membuat suatu panggung pementasan dan mengundang sejumlah aktor untuk memainkan sebuah kisah yang ia karang sendiri, terkait dengan 
pembunuhan seorang raja. Semua tindakan tersebut jelas Hamlet arahkan untuk mencari perhatian pamannya. Suatu sikap yang dapat dinilai pengecut, seolah Hamlet takut untuk berhadapan langsung dengan pamannya.

\section{MetodePenelitian}

Sistem kerja penelitian sastra dengan pendekatan Semiotik juga dapat dilakukan dengan dua model pembacaan, seperti yang telah diungkapkan sebelumnya (Suwardi,2004) yaitu heuristik dengan menelaah kata, bait, dan term karya sastra, serta pembacaan hermeneutik dengan menafsirkan karya sastra secara total. Beberapa halsebagai acuan yang juga menjadi perhatian dalam tindak penelitian sastra dengan pendekatan Semiotik berupa aspek utama, seperti yang diungkapkan Fokkema dan Kunne-Ibsch adalah theconstruction of abstract scientific models, explanatory models, schemes implication, dan yang diungkapkan riffaterre (1978) tiga lainnya seperti penciptaan arti (displacing of meaning), penyimpangan arti (distorting of meaning), serta pencipta anarti (creating of meaning).

\section{Hasil Penelitian}

Petikan puisi dalam drama Hamlet(Prince of Denmark) karya Shakespeare hal 192, dengan parafrase hal 193 .

There is a willow grows aslant a brook,

That shows his hoar leaves in the glassy stream:

Therewith fantastic garlands did she come

of-crow flowers, nettles, daisies, and long purples

That liberal shepherds give a grosser name,

But our cold maids do dead men's fingers call them:

There, on the pendet boughs her coronet weeds

Clambering to hang, an envious sliver broke:

When down her weedy trophies and herself

Fell in the weeping brook. Her clothes spread wide,

And mermaid-like, awhile they bore her up;

Which time she chanted snatched of old tunes,

As one incapable of her distress,

Or like a creature native and indued

Unto that element: but long it could not be

Till that her garments, heavy with their drink,

Pull'd the poor wretch from her melodious lay

To muddy death.

\section{Parafrase:}

There's a willow that grows by the edge of a stream, and its gray leaves are reflected in the clear water. There she came after having decorated herself with fantastic garlands of crow-flowers, nettles, daisies, and long purples to which the coarse Halaman | 66 
tongued shepherds give a coarser name, but which are called by our chaste maidens dead men's fingers. As she climbed to hang her garlands on the hanging branches, one of these branches broke, when both she and her garlands fell into the stream that seemed to lament her fate. Her clothes spread wide, and they held her up like a mermaid for a while: at such a time she sang fragments of old tunes as one insensible to her own distress, like a creature, taking to water as its own element; but this could not go on for long. Her garments weighed with moisture, dragged her down to a watery grave, putting an end to her plaintive song.

\section{Prime signifier: fell into the stream}

Prime signifier tersebut menyatakan bahwa Ophelia telah jatuh dalam kesedihan, keputus asaan, duka cita, dan kegilaan karena hidupnya yang sangat tragis ketika ia ditinggal oleh orang-orang yang dicintainya. Pertama, ayahnya mati dibunuh secara tidak sengaja oleh Hamlet. Kedua, saat Hamlet, pria yang ia cintai, harus diasingkan ke Inggris karena dianggap gila. Semua harapan dan cita-cita yang diimpikan untuk hidup bahagia telah sirna. Impiannya untuk hidup bersama dengan Hamlet telah musnah saat ia mengetahui kekasihnya diasingkan ke negeri yang jauh. Ophelia menjadi gila dengan kejadian tragis yang menimpanya tersebut, hingga suatu ketika ia benar-benar tenggelam dan meninggal dalam sungai. Hal ini menandakan bahwa ia telah menyatu dengan kesedihan dan cita-cita yang gagal ia raih untuk masuk dalam dunia keabadian. (Wardoyo, 25).

\section{Metafor dan metonimi:}

Di sini saya akan menganalisis puisi yang telah diparafrase pada halaman 193. Vehicle dan tenor dalam puisi :

\section{Vehicle---:--------tenor}

Willow--------Opheliayang bernasib tragis

The edge of a stream--------batas antara kewarasan dan kegilaan

Gray leaves----------kesedihan dan kemalangan

The clear water---------jiwa dan pikiran Ophelia

she came after having decorated herself--------Ophelia yang jatuh cinta

Fantastic garlands---------kekasih yang dicintai (Hamlet)

Which the coarse tongued shepherds give a coarser name---------orang-orang menganggap Hamlet sudah gila

But which are called by our chaste maidens dead men's fingers----------Ophelia tetap mencintai Hamlet dan tidak memedulikan pendapat orang tentang Hamlet

Crow flowers--------------Hamlet yang dianggap gila

Coarse tongued------------gunjingan orang tentang Hamlet

Shepherds-----------orang-orang disekitar Ophelia yang menentang hubungannya dengan Hamlet

Chaste maidens---------Ophelia 
She climbed to hang her garlands----------Ophelia berusaha untuk mewujudkan cintanya pada Hamlet

The hanging branches----------cita-cita dan impian Ophelia

These branches broke------------cita-cita yang kandas

when both she and her garlands fell into the stream------------Ophelia dan hamlet berada dalam hidup yang tragis dan malang. Hamlet dibuang ke Inggris sedangkan Ophelia kehilangan orang-orang yang dicintainya. Keduanya juga sama-sama dianggap gila

Fell into the stream-----------jatuh dalam kesedihan, duka cita, dan kegilaan.

Kesedihan dan duka cita Hamlet karena kematian ayahnya, pernikahan ibunya dengan Claudius, penampakan arwah ayahnya yang berpesan untuk membalaskan dendam atas kematiannya, serta konflik dalam dirinya atas keraguan untuk membalas dendam pada Claudius yang dianggap telah membunuh ayah kandungnya. Kemalangan dalam hidup Ophelia dikarenakan kematian ayahnya, cintanya pada Hamlet yang ditentang banyak orang, dan diasingkannya Hamlet ke Inggris. Semua hal tersebut mengakibatkan perilaku yang dianggap aneh dan gila pada Hamlet dan Ophelia.

Seemed to lament her fate------------Ophelia yang meratapi nasibnya

Like a mermaid---------seperti putri duyung yang selalu menanti kedatangan kekasihnya

Sang fragments-------------menyanyikan lagu-lagu sedih

Her own distress----------kemalangan Ophelia

Its own element------------menyatu dengan nasibnya yang malang

Weighed with moisture-----------tenggelam karena kesedihan dan dukanya

Dragged her down------------menenggelamkan Ophelia pada ketidakwarasan

Watery grave-----------kematian atau hidup yang abadi

Putting an end-----------mengakhiri kesedihan dan kemalangan hidup

Plaintive song----------lagu yang menyedihkan

\section{Makna dari kalimat dalam puisi di atas adalah:}

Ada seorang gadis, yakni Ophelia, yang berada di tepi hidupnya yang sangat tragis. Tepi di sini berarti batas antara kewarasan dan kegilaan. Kesedihan dan kemalangan Ophelia tersebut terlihat dari jiwa dan pikirannya.

There she came after having decorated herself

with fantastic garlands of crow-flowers, nettles, daisies, and long purples

to which the coarse tongued shepherds give a coarser name,

but which are called by our chaste maidens dead men's fingers.

\section{Makna dari kalimat dalam puisi di atas adalah:}

Ophelia menemukan kebahagiaan saat ia jatuh cinta pada Hamlet, yang meskipun dianggap gila oleh orang-orang di istana, namun ia tidak peduli dan tetap mencintainya.

As she climbed to hang her garlands on the hanging branches,

one of these branches broke, 
when both she and her garlands fell into the stream

that seemed to lament her fate.

\section{Makna dari kalimat dalam puisi di atas adalah:}

Ophelia mempunyai impian untuk hidup bahagia dengan orang yang dicintai, ternyata keinginannya harus kandas, saat dia dan Hamlet harus berpisah. Hamlet yang dianggap gila dan diasingkan ke Inggris membuat Ophelia makin merana setelah kematian ayahnya, yang tidak sengaja dibunuh oleh Hamlet. Dengan kejadian ini Ophelia senantiasa meratapi nasib dan akhirnya menjadi gila.

Her clothes spread wide, and they held her up like a mermaid for a while:

at such a time she sang fragments of old tunes as one insensible to her own distress, like a creature, taking to water as its own element;

but this could not go on for long.

\section{Makna dari kalimat dalam puisi di atas adalah:}

Ophelia menjadi seperti putri duyung yang selalu menanti kedatangan kekasihnya dengan menyanyikan lagu-lagu sedih yang mengisahkan kemalangan dan kesedihannya. Masa ini dialami Ophelia saat ia menjadi gila karena guncangan beberapa peristiwa tragis yang menimpanya dan cita-citanya untuk hidup bersama dengan Hamlet telah kandas. Keadaan Ophelia yang hilang kewarasan ini tidak berlangsung lama.

Her garments, weighed with moisture,

dragged her down to a watery grave,

putting an end to her plaintive song

\section{Makna dari kalimat dalam puisi di atas adalah:}

Kesedihan dan kemalangan yang dirasakan Ophelia membawanya pada kematian, saat ia benar-benar tenggelam dalam sungai. Hal ini mengakhiri hidupnya yang tragis dan membawanya pada hidup yang abadi.

\section{Skema Naratif Dasar}

grows by the edge of a stream

she came after having decorated herself with fantastic garlands

she climbed to hang her garlands

these branches broke

she and her garlands fell into the stream

she sang fragments of old tunes

dragged her down to a watery grave

Dari beberapa skema naratif dasar yang terdapat di atas telihat tentang Ophelia yang bernasib malang dengan menghadapi beberapa peristiwa dalam kehidupannya. Dengan kalimat grows by the edge of a stream menceritakan tentang Ophelia yang berada di ambang batas kewarasan dan kegilaan sehubungan dengan berbagai nasib tragis yang menimpanya. Hidupnya seakan dihantui dengan macammacam kesedihan yang sepertinya telah ditakdirkan akan terjadi di masa depannya. 
Pada kalimat she came after having decorated herself with fantastic garlands menceritakan tentang cita-cita dan impian Ophelia tentang kekasih yang ia cintai. Ia ingin hidup bahagia dengan Hamlet sampai akhir hidupnya. Ophelia sudah merencanakan berbagai hal indah yang akan ia jalani di hari depannya dengan Hamlet. Fantastic garlands bisa berarti orang yang ada di hidupnya, yang mencintai dan ia cintai namun juga bisa berarti beberapa hal yang ia buat untuk masa depannya, diantaranya menjadi istri yang baik, anak yang dapat membahagiakan ayahnya, dan memiliki kehidupan yang bahagia untuk selamanya.

Kalimat she climbed to hang her garlands berarti bahwa ia akan berusaha untuk mewujudkan segala impian dan cita-citanya. Ophelia akan berjuang untuk mempertahankan cintanya yang ternyata ditentang oleh banyak pihak, termasuk oleh ayahnya, raja dan ratu. Ophelia berusaha meyakinkan orang-orang tersebut bahwa ia akan tetap mencintai Hamlet apapun yang akan terjadi. Ia sudah yakin dengan pilihan dan perasaanya cintanya pada Hamlet, dan siap menghadapi apapun rintangan yang ada. Rasa cinta Ophelia pada Hamlet sudah sejak lama terjalin di antara mereka, namun mereka berusaha menutupi rahasia tersebut karena Hamlet berencana akan membunuh pamannya, yang adalah raja Denmark, menggantikan ayah Hamlet yang meninggal.

Pada kalimat these branches broke melukiskan harapan-harapan dan citacita Ophelia ternyata telah kandas. Berbagai impian indah yang telah ia pikirkan dan rencanakan ternyata harus gagal. Ophelia harus mengahadapi berbagai peristiwa tragis yang mengguncang hidupnya. Selain ia harus kehilangan ayahnya, ia juga harus kehilangan hamlet, pria yang ia cintai. Lenyap sudah sumber kebahagiaan dengan tidak adanya orang-orang yang ia kasihi. Kata branches bisa diartikan sebagai cita-cita dan impian Ophelia, bisa juga diartika sebagai ayahnya yang tewas dan Hamlet yang diasingkan ke Inggris. Dengan berbagai kemalangan ini, Ophelia kehilangan masa depan bahagia yang ia impikan. Ia telah kehilangan harapan untuk membahagiakan ayahnya. Ophelia juga sudah tidak mempunyai harapan untuk menjadi istri Hamlet seperti yang ia inginkan.

Kalimat she and her garlands fell into the stream berarti bahwa Ophelia dan segala impiannya telah jatuh dalam kemustahilan. Kata stream berarti keadaan pikiran dan jiwa yang telah kehilangan kewarasannya. Ophelia yang harus didera dengan banyak kejadian memilukan, berubah menjadi orang yang terganggu mentalnya. Bisa juga diartikan bahwa Ophelia dan Hamlet telah jatuh dalam kegilaan. Ophelia telah menjadi gila dengan berbagai nasib yang menimpanya, sedangkan Hamlet dianggap gila oleh orang-orang istana dan diasingkan ke Inggris. Kata garlands bisa diartikan sebagai impian-impian Ophelia atau bisa juga diartikan sebagai Hamlet. Hamlet yang selama ini menjadi kekasihnya, telah dianggap gila oleh orang istana dalam rangka menyingkirkannya dari Denmark. Kalimat ini yang menjadi penanda utama pada puisi ini, karena pada kalimat inilah segala sesuatu menjadi tidak mungkin terjadi lagi. Kalimat ini juga bisa merupakan klimaks dari petikan puisi tersebut.

Halaman | 70 
Kalimatshe sang fragments of old tunes menceritakan tentang Ophelia yang setelah menjadi gila selalu menunggu Hamlet dengan nyanyiannya. Ia seperti putri duyung yang selalu menantikan kedatangan kekasihnya dengan lagu-lagu yang dinyanyikan. Ophelia dalam kegilaannya ternyata masih setia menunggu Hamlet setiap hari. Segala impian yang ia dambakan masih melekat dalam benaknya. Ia sangat berharap suatu ketika Hamlet datang kembali padanya. Kesedihan dan kemalangan Ophelia terdengar jelas dengan lagu-lagu sedih yang ia nyanyikan. Hal yang dilakukan Ophelia merupakan bentuk kesetiaan seorang wanita terhadap kekasih yang ia cintai. Walaupun ia kehilangan kewarasannya, namun ia tidak kehilangan kesetiannya. Hal ini menambah nuansa sedih dalam puisi tersebut.

Kalimat dragged her down to a watery grave menceritakan tentang kesedihan dan kemalangan yang makin menarik Ophelia pada kegilaanya. Ia akhirnya menenggelamkan diri di sungai dan meninggal. Ia telah menyatu dengan semua harapan, impian, dan cita-citanya dalam keabadian. Kata watery grave diartikan sebagai alam keabadian yang akan membuat dirinya tenang. Meskipun di alam nyata ia tidak bisa mewujudkan impiannya, namun di alam kematian, ia akan menemukan kebahagiaan yang ia dambakan selama ini.

\section{Syntagmatik dan paradigmatik pada petikanpuisi :}

\begin{tabular}{|l|l|l|}
\hline no & Impian Ophelia & kenyataan yang dihadapi Ophelia \\
\hline 1 & dapat mencintai Hamlet & banyak orang yang menentang \\
\hline 2 & Hamlet dapat menjadi raja & Hamlet diasingkan ke Inggris \\
\hline 3 & dapat membahagiakan ayahnya & ayahnya tewas dibunuh \\
\hline 4 & hidup dengan wajar dan bahagia & Ophelia menjadi gila \\
\hline 5 & dapat menjadi istri yang setia & $\begin{array}{l}\text { hanya dapat meratapi Hamlet yang } \\
\text { diasingkan }\end{array}$ \\
\hline 6 & $\begin{array}{l}\text { hidup bahagia dengan Hamlet } \\
\text { selamanya. }\end{array}$ & tewas tenggelamdi sungai \\
\hline
\end{tabular}

\section{Dramatic Situation}

Pada petikan puisi drama Hamlet ini, situasi dramatik yang digunakan adalah yang (c) dan (d) yaitu : (c) adalah sebuah struktur dimana si persona tidak menyapa addressee (lawan tutur) tertentu secara khusus. Persona pada puisi adalah Queen of Denmark yang sedang menceritakan tentang kematian Ophelia. Pada puisi tersebut, Queen tidak menunjuk seseorang tertentu sebagai lawan tuturnya.Queen (Gertrude) hanya menggambarkan berbagai kesedihan yang menyertai hidup Ophelia.

Poin yang (d) adalah sebuah konstruksi dimana si persona bisa diidentifikasikan sebagai si penyair, namun addresseenya (lawan tuturnya) sama sekali bukan pembaca. Bisa juga persona pada puisi ini adalah si penyair sendiri yang berusaha menceritakan betapa tragis nasib Ophelia dan berbagai kemalangan di akhir hidup yang membawanya pada kegilaan dan kematian. 


\section{Simpulan}

Dalam analisis puisi Hamlet yang dikaji dengan menggunakan semiotika, maka dapat diketahui tentang berbagai tanda atau makna yang terdapat dalam kalimat dan kata dalam puisi tersebut. Beberapa tokoh dalam puisi tersebut antara lain Hamlet dan ophelia menunjukkan suasana hati dan tindakan-tindakan yang dilakukan berkaitan dengan tanda dan makna puisi Hamlet. Segala bentuk bahasa yang dipergunakan dalam membangun karya sastra dengan kandungan makna didalamnya akan menjadi sebuah tanda. Dengan demikian, bahasa karya sastra dapat dikatakan sebagai ikon, indek, maupun symbol yang disajikan dan dihadirkan dengan makna. Ilmu yang mendasari proses penelusuran dan upaya pemahaman bahasa sebagai tanda atas makna tertentu yang dimiliki karya sastra disebut Semiotika.

\section{Daftar Pustaka}

Ambarini AS, Nazla Maharani Umaya,2015, Semiotika, Teori dan Aplikasi pada Karya sastra, IKIP PGRI Semarang Press, Semarang.

Nyoman, Kutha Ratna, 2004, Teknik Penelitian Sastra, Jakarta: Gramedia

Pradopo, Rahmat Djoko, 2004, Kritik Sastra Modern, Yogyakarta: Gama Media

Shakespeare, William. 1975. Hamlet, Prince of Denmark. Jakarta: PT Bumi Restu.

Wardoyo, S. (2005). Dover Beach: Semiotics in Theory and Practice. TEFLIN Journal, vol. 16, Num. 2, August 2005.

Wardoyo, S. (2005). Semiotika dan Struktur Narasi, Kajian Sastra, vol. 29, No. 1, Januari 2005.

Segers, Rien T. 2000. Evaluasi Teks Sastra. Yogyakarta: Adicita Karya Nusa

Suwardi, Endraswara, 2004, Metode Penelitian Sastra, Yogyakarta: Gramedia 